\title{
Analysis of natural history of the diaphragmatic injury on the right in mice
}

\section{Análise da evolução natural dos ferimentos diafragmáticos à direita em ratos}

\author{
Benedito Aparecido Caiel ${ }^{1,2}$; Cristovam Scapulatempo Neto ${ }^{3}$; Arthur Soares de Souza Júnior ${ }^{4}$; Roberto SaAd Júnior ${ }^{1}$
}

\author{
A B S T R A C T
}

\begin{abstract}
Objective: to evaluate natural evolution of right diaphragmatic injury after the surgical removal of a portion from hemi diaphragm. Methods: the animals were submitted to a surgical removal of portion from right hemi diaphragm by median laparotomy. The sample consists of 42 animals being 2 animals from pilot project and 40 operated animals. And the variables of the study were herniation, liver protection, healing, persistent diaphragm injury, evaluation of 16 channels tomography and the variables "heart rate" and "weight". Results: we analyzed 40 mice, we had two post-operative deaths; we had 17 animals in this group suffered from herniation (42.5\%) and 23 animals didn't suffer from herniation (57.5\%). Analyzing the tomography as image method in the evaluation of diaphragmatic hernia, we had as a method with good sensitivity (78.6\%), good specificity (90.9\%), and good accuracy $(86.1 \%)$ when compared to necropsy. Conclusion: there was a predominance of healing of right hemi diaphragm, the size of initial injury didn't have influence on occurrence of the liver protection or hernia in mice.
\end{abstract}

Key words: Thoracic Surgery. Wound Healing. Diaphragm. Animal Experimentation. Animal Experimentation. Hernia, Diaphragmatic, Traumatic. Thoracic Injuries.

\section{INTRODUCTION}

solated diaphragmatic injuries are a major challenge for physicians working in the field of traumatology. They may go unnoticed both by the uncertainty of their evolution and by the acute or chronic clinical repercussions ${ }^{1,2}$.

The leading cause of diaphragmatic lesions are the penetrating injuries in the thoracoabdominal transition zone (TATZ), limited anteriorly by the fourth intercostal space, laterally by the sixth intercostal space, posteriorly by the tip of the scapula and inferiorly by the epigastric region and the costal margin ${ }^{3}$. Such penetrating injuries to the TATZ can display up to $48 \%$ of diaphragmatic injurie 4 . The most affected organs in diaphragmatic injuries are: lung, stomach, liver, spleen and colon, the left hemidiaphragm being the most affected both in penetrating and blunt trauma; stabbing wounds are the most frequent, and, in most cases, have less than two centimeters ${ }^{5}$. Even with a substantial number of publications showing the high incidence of diaphragmatic injuries in TATZ trauma, this incidence is still unclear, given that a large numbers of these lesions still goes unnoticed ${ }^{1-6}$.

Symptoms of patients with diaphragmatic injuries can range from referred pain in the shoulder, decreased chest expansion, bowel sounds on auscultation, dug abdomen or even no symptoms, and patients may progress from asymptomatic in and isolated small injuries to circulatory collapse, with severe respiratory failure, resembling tension pneumothorax ${ }^{7}$. The most common symptoms are related to the digestive and respiratory systems, however, it is estimated that $25 \%$ of these patients may go asymptomatic ${ }^{8}$.

For the diagnosis of a diaphragmatic injury, the main tools are the clinical examination and the imaging studies. A simple chest X-ray often shows nonspecific signs, such as hemothorax, pneumothorax, elevated hemidiaphragm and even a simple opacity in the costophrenic angle and, often, these changes may persist after thoracic drainage ${ }^{9}$. Examinations with contrast media may render diagnoses when there is herniation of abdominal structures into the chest, but most of the injuries that affect the diaphragm are small, resulting in a low rate of herniations ${ }^{10,11}$.

The use of computed tomography with threedimensional reconstruction decreases the chances of a false negative. There are reports showing failure in diagnosing diaphragm lesions with the use of conventional tomography ${ }^{12-15}$. Magnetic resonance imaging has shown promising results when evaluating diaphragmatic lesions in chest and abdomen, injuries but it is still a method with little use, is not yet available in most trauma services, is costly and requires a long time for its realization ${ }^{16}$.

1. Irmandade da Santa Casa de Misericórdia de São Paulo, SP, Brasil; 2. Irmandade da Santa Casa de Misericórdia de Barretos, SP, Brasil; 3. Departamento de Anatomia Patológica - Hospital de Câncer de Barretos, SP, Brasil; 4. Departamento de Radiologia Torácica - Ultra-X São José do Rio Preto, SP, Brasil. 
Even when using all the above cited diagnostic tools along with a clinical exam, still we cannot achieve a good sensitivity and specificity of these tests for diaphragmatic injury, especially when faced with diaphragmatic injuries without hernia and with the patient stable. Healing is supposed to take place in parts of these injuries, many of whom, non-operated, showed good recovery without herniation ${ }^{8}$.

Nowadays, there is still no consensus in the treatment of diaphragmatic injuries in stable patients, and in most emergency departments we did not find thoracoscopy as a test for routine use. We then decided to evaluate the natural evolution of diaphragmatic injuries after resection of a portion of the right diaphragm.

\section{METHODS}

We used 40 Rattus norvegiccus albinus rats, known as the albino Wistar strain, with about 90 days of life (250g). They were kept in collective cages for ten days, with a population density of five animals per cage, with free and unrestricted access to water and food given to rodents, and light / dark cycle of 12 hours. The research project was submitted to the Ethics in Animal Experimentation Commission the of Dr. Paulo Prata Health Sciences School of Barretos (FACISB), which issued a favorable opinion under protocol 009/2013.

The identification of each animal was performed by numbered hidrocolor fountain on the tail and ear. After performing the surgical procedure, the animals were housed in individual cages. During the postoperative period of 30 days, we measured the heart rate and weight on days 0,5 , $10,15,20,25$ and 30 . The heart rate was measured with the aid of a stethoscope. Weight was measured with a SF400 CE precision balance. After this period, the animals underwent a CT scan of the chest and, soon after, euthanasia through a laparotomy associated with a double thoracotomy. During the autopsy we evaluated: 1) diaphragmatic hernia; 2) Liver protection; 3) diaphragmatic healing; and 4) persistent diaphragmatic injury without hernia or protection. Subsequently, we compared the occurrence of hernia or protection in the chest tomography with microscopy, checking whether the initial size of the lesion and the local inflammatory reaction (size of fibrosis and thickness of the membrane) influenced the occurrence of hernia or protection in the diaphragmatic injury.

Under general anesthesia, we performed a laparotomy and dissection of the right diaphragm in two Wistar rats of approximately $250 \mathrm{~g}$ weight. The right diaphragm was withdrawn from one rat for the calculation of its total area, and from the other, to define the the portion of the right hemidiaphragm to be removed. The size of the lesion and the calculation of the right diaphragm area were measured using a computer graphics program (AutoCAD ${ }^{\circledR}$ by Autodesk ${ }^{\circledR}$, version 2006), using integral calculus. We could not standardize the withdrawal of exactly $10 \%$ of the diaphragm due to difficulties of finding a surgical instrument able to extract a proper portion of the assessed hemidiaphragm and to anatomical and physiological conditions.

We performed the anesthesia to animals subjected to fasting ten hours before the procedure. The drugs chosen were ketamine hydrochloride at a dose of $50 \mathrm{mg} / \mathrm{kg}$ intraperitoneally, and $2 \%$ xylazine $5 \mathrm{mg} / \mathrm{kg}$, intraperitoneally. The animals were ventilated with a continuous positive airway pressure (CPAP) mask fitted with a rubber tube at pressure $1.5 \mathrm{Kgf} / \mathrm{cm}^{2}$ and positive endexpiratory pressure (PEEP) $5 \mathrm{~mm}$ of water, by an oxygen concentrator.

Once the anesthesia ensued and after abdominal trichotomy, they underwent laparotomy measuring $3 \mathrm{~cm}$ in length, starting under the xiphoid process for viewing and incision of the right diaphragm with a scalpel (blade 11) to carry out a ipsilateral pneumothorax and cause pulmonary collapse, thus avoiding lung injury when performing the diaphragmatic injury. We performed resection of a portion of the right diaphragm on 40 animals, between the costal insertion and the central tendon of the diaphragm, without including it in the place where we had held the pneumothorax (Figure 1). There was a variation of $5.18 \%$ to $20 \%$ in the size of the resection portion withdrawn. Upon completion of the injury, we placed an open anatomical clamp next to the injury and photographed for later calculation of lesion size by the computer graphics software "AutoCAD", since we already had knowledge of the size of the right hemidiaphragm. After the procedure and before the laparotomy closure, we held a lung hyperinflation followed by Valsalva maneuver to empty the pneumothorax and prevent atelectasis in the immediate postoperative period.

All animals were assisted till the end of anesthetic procedure and hydrated after surgery by applying $5 \mathrm{ml}$ of

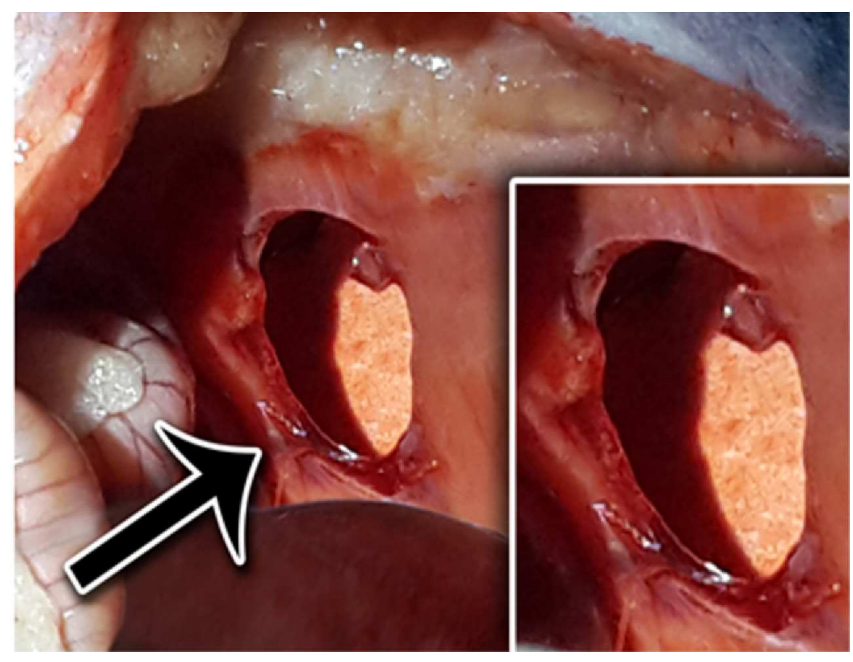

Figure 1 - Photograph of the surgical wound caused by the removal of a portion of the right hemidiaphragm. 
$0.9 \%$ saline per animal, performed by subcutaneous injection, going through a recovery period in a heated room. After anesthetic recovery, the animals were returned to their individual cages, where they received food and water throughout the postoperative period (30 days). Analgesia was performed to severe pain during the first four days with tramadol hydrochloride, $50 \mathrm{mg} / \mathrm{kg}$ subcutaneously three times a day, associated with acetaminophen $1-2 \mathrm{mg} / \mathrm{ml}$ diluted in water and given orally for seven days.

After 30 days, the animals were anesthetized and underwent chest computed tomography (16 channels), to observe the occurrence of diaphragmatic hernia. Upon completion of the CT scan, the animals underwent laparotomy and double thoracotomy and were killed according to the international euthanasia standards in laboratory animals by intracardiac lethal injection of $10 \%$ Potassium chloride $(\mathrm{KCL})$ at a dose of $2 \mathrm{mmol} / \mathrm{kg}$. We then started the autopsy study. After wide opening of cavities, we recorded the position of abdominal organs and how they were found: in the abdominal cavity; in the chest cavity; or adhered to the diaphragm making the protection of the injury, assessing the occurrence of healing, protection or hernia. Completed the autopsy, we withdrew the entire portion of the right diaphragm together with the viscera herniated or attached to it for subsequent histological analysis.

The specimen (with or without diaphragm adhered structures) was removed and immersed in a jar containing 10\% formaldehyde. Tissue sections were prepared in the routine pathology laboratory for the slides preparation. One slide was stained with hematoxylin-eosin (HE) for classical morphologic assessment and the other was stained with the Masson technique for evaluation of fibrosis. Microscopic evaluation was a blinded procedure, in a double microscope observation.

Initially examining the slide stained by $\mathrm{HE}$, we analyzed the histological changes, the structures that were attached to the diaphragmatic injury and the occurrence of liver protection or liver herniation and other abdominal viscera. The examination of the slides stained by the Masson technique quantified the area of greatest fibrous thickness of the membrane that covered the diaphragm on the edge of the lesion and the extent of fibrosis from the edge of the surgical injury.

Forty animals constituted the study group. Two animals died, one on the tenth day after surgery and another in the 11th, both being included in the study.

We performed descriptive analyzes of the data by calculating the mean, standard deviation, minimum, maximum, median and 25th and 75th percentiles, for the quantitative variables and frequency tables for qualitative variables. We used the Kolmogorov-Smirnov test to assess normality of the numerical variables. For all variables we obtained $p>0.05$.

To verify whether the size of the initial lesion was statistically equal between the variables "protection" and "herniated", and to compare the size of the diaphragm initial injury with the thickness of the membrane and the extent of fibrosis (microscopy), we used the Student's t-test for independent samples.

Considering the autopsy as the gold standard, we checked the agreement between microscopy and tomography. For this, for the three variables (necropsy, microscopic and tomography) we classified each animal as protection or hernia, and subsequently compared the groups. We calculated the sensitivity, specificity, accuracy and their respective confidence intervals (95\%). Reproducibility between the methods was evaluated by the Kappa coefficient. To compare the evolution of weight and heart rate over time between groups, we used the Analysis of Variance (ANOVA) with mixed design. For this, we verified the effect of the interaction between time and group, the effect of time and the effect of the group.

\section{RESULTS}

We operated 40 rats. There were two deaths, with operative mortality of $5 \%$. The deaths occurred on the tenth and 11 th days postoperatively, the two animals had hernia and both were included in the study.

The result of the autopsy, according to the distribution of the evolution pattern of the lesion, showed liver protection in $50 \%$ of animals; there was herniation of abdominal structures, predominantly the liver followed by the omentum, large intestine, small intestine and spleen in $42.5 \%$ of animals and healing occurred in $7.5 \%$ (Table 1).

When we compared the variables protection and hernia with the size of the initial lesion, which varied from $5.18 \%$ to $20 \%$ of right diaphragm removed, we found no statistically significant difference between them (Table 2).

When comparing the results of tomography and the microscopic analysis of the material in relation to what we consider the gold standard (necropsy), we noted that both microscopy and chest computed tomography showed good sensitivity (hernia), good specificity (protection) in evaluation of diaphragmatic hernia (Tables 3 and 4). Considering the reproducibility between the microscopy and tomography with the autopsy, we found acceptable Kappa coefficients. For microscopy versus autopsy it was 0.734 ( $p$ $<0.001$ ), while for computerized tomography, 0.704 ( $p$ $<0.001)$

This heart rate evaluation showed a statistical significance with respect to time, all animals displaying decreased heart rate over the days postoperatively $(p<0.001)$, but there was no statistical significance between protection and hernia groups $(p=0.250)$. Regarding the variable weight, we noted that there were significant differences over time $(p<0.001)$, all gaining weight during the postoperative period; and when comparing rats with protection and hernia, those with protection had more weight gain $(p=0.039)$ than those who had hernia. 
Table 1 - Macroscopic, microscopic and tomographic characterization of injuries.

\begin{tabular}{llll}
\hline Variable & Category & $\mathrm{n}$ & \% \\
\hline Macroscopy & Protection & 23 & 57,5 \\
& Hernia & 17 & 42,5 \\
Microscopy * & Protection & 15 & 40,5 \\
& Hernia & 22 & 23,5 \\
Hernia diagnosed by tomography ** & Protection & 23 & 36,1 \\
Total & Hernia & 13 & 100 \\
\hline
\end{tabular}

* There are missing values, since it was not possible to manufacture and further evaluate the slides of three rats.

** There are missing values, since it was not possible to complete the tomographic report of four rats.

Table 2 - Comparison of the size of the initial diaphragm injury of the hernia and the protection groups.

\begin{tabular}{|c|c|c|c|c|c|c|c|c|c|c|}
\hline Group & $n$ & Average & $\begin{array}{l}\text { Standard } \\
\text { deviation }\end{array}$ & Minimum & $1^{\text {st }}$ & Quartile & Median $3^{\text {rd }}$ & Quartile & Maximum & $P$ \\
\hline Protection & 23 & 10.48 & 3.72 & 5.76 & & 6.03 & 9.41 & 12.75 & 19.37 & 0.530 \\
\hline Hernia & 17 & 9.69 & 4.16 & 5.18 & & 5.18 & 8.29 & 11.79 & 20.00 & \\
\hline
\end{tabular}

In assessing the size of the initial lesion (macroscopic), the thickness of the diaphragm membrane at the injury site and the size of fibrosis at the site of injury (microscopic) in relation to the variables hernia and protection (microscopy), we noted no statistical significance that might explain the occurrence of hernia or protection (Table 5). When we evaluated the occurrence of persistent diaphragm injury without protection or hernia in both microscopy and in macroscopic, we found no cases of such injury in the animals studied.

\section{DISCUSSION}

When the diagnosis is made and the complications of diaphragmatic injury are repaired in the acute phase, there is a low morbidity and mortality. However, the results are different when it comes to a complication of diaphragmatic lesion with months or years of evolution 17,18 , There are rates of approximately $48 \%$ mortality and 30\% morbidity when treatment is started too late, reaching $80 \%$ of morbidity and mortality ${ }^{13}$.
The reason that led some authors to reveal the possibility of spontaneous healing of diaphragmatic injuries was that, in clinical practice, only a relatively small number of patients with penetrating TATZ injuries developed hernia during clinical monitoring ${ }^{9.19}$

The pressure gradient between the pleural and peritoneal cavities, the constant movement of the diaphragm during the respiratory cycle and the radial tension between the center and its parietal tendon insertions are cited as factors that prevent diaphragmatic healing after trauma ${ }^{20}$.

In a study ${ }^{21}$ with a porcine model using laparotomy, diaphragmatic injuries of $1.5 \mathrm{~cm}$ to $2 \mathrm{~cm}$ in length located at the central tendon of a hemidiaphragm and muscle of the contralateral hemidiaphragm, with pleural drainage for emptying of pneumothorax, using general anesthesia and sacrificing the animals after six weeks, they concluded that most stabbing injuries, regardless of the location, the central tendon or muscle part, heal spontaneously, not justifying the evaluation of diaphragm conditions in all patients with injuries in the thoracoabdominal transition area.

Evaluating existing studies in the literature, we found that healing is the rule dir perforating injuries to the

Table 3 - Evaluation of the occurrence of hernia in microscopy and chest tomography compared with necropsy.

\begin{tabular}{|c|c|c|c|c|c|}
\hline & & & & & \\
\hline & & & & & \\
\hline & & $\mathrm{N}$ & $\%$ & $\mathrm{n}$ & $\%$ \\
\hline Microscopy - & Protection & 15 & $75.0 \%$ & 0 & $0.0 \%$ \\
\hline & Hernia & 5 & $25.0 \%$ & 17 & $100.0 \%$ \\
\hline Tomography - & Protection & 20 & $90.9 \%$ & 3 & $21.4 \%$ \\
\hline & Hernia & 2 & $9.1 \%$ & 11 & $78.6 \%$ \\
\hline
\end{tabular}


Table 4 - Evaluation of sensitivity and specificity of Microscope and multidetector chest tomography in the evaluation of diaphragmatic Hernia.

\begin{tabular}{lccc}
\hline Assessment & Sensitivity & Specificity & Accuracy \\
\hline Microscopy95\% Cl & $100.0 \%$ & $75.0 \%$ & $86.5 \%$ \\
Tomography & {$[81.57 \% ; 100.0 \%]$} & {$[53.1 \% ; 88.8 \%]$} & {$[72.0 \% ; 94.1 \%]$} \\
$95 \% \mathrm{Cl}$ & $78.6 \%$ & $90.9 \%$ & $86.10 \%$ \\
\hline
\end{tabular}

Table 5 - Comparison of the initial injury size with the microscopic variables: 1) Thickness of the injury membrane; 2) Size of the fibrosis on the injury site.

\begin{tabular}{|c|c|c|c|c|c|c|c|c|c|c|}
\hline $\begin{array}{l}\text { Variable } \\
\text { Group }\end{array}$ & $\mathrm{n}$ & Average & $\begin{array}{l}\text { Standard } \\
\text { deviation }\end{array}$ & Minimum & $1^{\text {st }}$ Quartile & Median & $3^{\text {rd }}$ & Quartile & Maximum & $P$ \\
\hline \multicolumn{11}{|c|}{ Size of the initial diaphragmatic injury } \\
\hline Protection & 15 & 10.11 & 3.73 & 5.76 & 6.76 & 9.41 & & 12.62 & 19.37 & 0.866 \\
\hline Hernia & 22 & 9.89 & 3.95 & 5.18 & 6.76 & 8.50 & & 11.79 & 20.00 & \\
\hline \multicolumn{11}{|c|}{ Membrane thickness in mm (Microscopy) } \\
\hline Protection & 15 & 0.25 & 0.32 & 0.01 & 0.08 & 0.11 & & 0.20 & 1.00 & 0.379 \\
\hline Hernia & 22 & 0.16 & 0.32 & 0.00 & 0.03 & 0.05 & & 0.10 & 1.50 & \\
\hline \multicolumn{11}{|c|}{ Fibrosis size in mm (Microscopy) } \\
\hline Protection & 15 & 0.61 & 0.41 & 0.15 & 0.30 & 0.45 & & 0.90 & 1.40 & 0.645 \\
\hline Hernia & 22 & 0.70 & 0.68 & 0.20 & 0.30 & 0.48 & & 0.82 & 3.30 & \\
\hline
\end{tabular}

thoracoabdominal transition zone, which is contrary to what is done in clinical practice. It is worth remembering that, in most cases, the wounds are small $(2 \mathrm{~cm}$ in most), between the central tendon and the costal wall, especially on the left, since most of the perpetrators are right-handed ${ }^{22}$.

In our experimental model, we sought to create a condition of healing difficulty when we removed a portion of the right hemidiaphragm, what none of the cited studies did, hampering the approach of the damaged edges, which would be conducive to wound healing.

We were careful to specify the exact extent of the injury we carried out, which was located between the central tendon of the right hemidiaphragm and its insertion in the lateral thoracic wall, causing in this way an injury in one of the phrenic nerve branches, a fact which further corroborated the poor healing of the injury caused. We found, after reviewing the literature, that most works did not detail the site of injury, but one article ${ }^{21}$ which detailed and assessed the extent of the injury in the two main regions of the diaphragm (the central tendon and muscle part).

Regarding the anesthetic technique, the drugs chosen for the anesthesia were ketamine hydrochloride and xylazine to cause good analgesia, not having hypotensive action on the cardiovascular system and hardly causing respiratory depression. In this way, we did not establish a definitive airway and only held a ventilatory assistance by a rubber with intermittent pressure of $5 \mathrm{~mm}$ water, adapted as a CPAP, getting a good lung expansion during the procedure and a good evacuation of the pneumothorax, with no need of pleural drainage during the closure of the abdominal cavity.

We chose the median abdominal incision, approximately $3 \mathrm{~cm}$ in length from the xiphoid appendix, as a gateway to the right hemidiaphragm. Although there are reports of diaphragmatic dysfunction associated with laparotomy ${ }^{23}$, we did not observe this fact, nor did other authors who used models similar to ours ${ }^{24,25}$. This might be explained by the rapidity of the procedure and also by the use of CPAP, as we found no respiratory fatigue of the animals after the end of anesthesia.

The determination of 30 days for observation time of was based on a work by Perlingeiro et al. ${ }^{9}$, showing no statistical significance between the dead animals in the period 11 th to 60 th day with the 120th to 150th days.

To this day, no one knows the exact timing of the herniation, since injuries undiagnosed in the acute phase will be discovered only when there are symptoms, often unspecific ${ }^{26}$, and sometimes dramatically, with drastic obstructive symptoms or acute respiratory failure, in most cases one to three years after the traumatic event. Symptoms such as abdominal pain, nausea, vomiting, constipation, dyspnea and chest pain are related to the 
progressive herniation of abdominal organs into the chest ${ }^{27}$.

In our study with 40 animals, there were two deaths with great herniation of abdominal organs into the chest cavity, there was protection of the injury in $50 \%$ of animals, complete healing of the diaphragm in $7.5 \%$, and even a possible healing with muscles filling the wound. We found no cases of persistent injury without protection or herniated diaphragm. It was not possible in this study to determine why some animals evolve with hernia and others do not, since we showed that the lesion size was not statistically significant as for the occurrence of diaphragmatic hernia or protection. Many questions are still to be answered. It is still difficult to understand the natural evolution of perforating injuries to the thoracoabdominal transition zone.

In conclusion, there was a predominance of healing of the right hemidiaphragm injury, yet the size of the initial injury did not influence the occurrence of liver protection or hernia.

\title{
R E S U M O
}

\begin{abstract}
Objetivo: avaliar a evolução natural do ferimento diafragmático à direita após a retirada cirúrgica de uma porção do hemidiafragma. Métodos: os animais foram submetidos à ressecção de uma porção do hemidiafragma à direita através da laparotomia mediana. Foram operados 40 ratos. As variáveis analisadas foram: herniação, proteção hepática, cicatrização, lesão persistente do diafragma, avaliação da tomografia computadorizada, frequência cardíaca e peso. Resultados: foram analisados 40 ratos. Houve duas mortes no pós-operatório. Dezessete animais tiveram herniação (42,5\%) e 23 (57,5\%), não. Analisando emprego da tomografia computadorizada na avaliação da hérnia diafragmática, tivemos um método com boa sensibilidade (78,6\%), boa especificidade (90,9\%) e boa acurácia $(86,1 \%)$ quando comparados com a necrópsia. Conclusão: houve predomínio de cicatrização do hemidiafragma à direita e o tamanho da lesão inicial não influenciou na ocorrência de proteção hepática ou hérnia em ratos.
\end{abstract}

Descritores: Cirurgia Torácica. Cicatrização. Diafragma. Experimentação Animal. Hérnia Diafragmática Traumática. Traumatismos Torácicos.

\section{REFERENCES}

1. Leppäniemi A, Haapiainen R. Occult diaphragmatic injuries caused by stab wounds. J Trauma. 2003;55(4):646-50.

2. Von Bahten LC, Smaniotto B, Kondo W, Vasconcelos CN, Range M, Laux GL. Papel da laparoscopia no trauma abdominal penetrante. Rev Col Bras Cir. 2005;32(3):127-31.

3. Asensio JA, Demetriades $D$, Rodriguez A. Injury to the diaphragm. In: Mattox KL, Feliciano DV, Moore EE, editors. Trauma. 4th ed. New York: McGraw-Hill; 2000. p.603-32.

4. Zantut LF, Ivatury RR, Smith RS, Kawahara NT, Porter JM, Fry WR, et al. Diagnostic and therapeutic laparoscopy for penetrating abdominal trauma: a multicenter experience. J Trauma. 1997;42(5):825-9; discussion 829-31.

5. Ordog GJ, Wasserberger J, Balasubramanium S, Shoemaker W. Asymptomatic stab wounds of the chest. J Trauma. 1994;36(5):6804.

6. Friese RS, Coln CE, Gentilello LM. Laparoscopy is sufficient to exclude occult diaphragm injury after penetrating abdominal trauma. J Trauma. 2005:58(4):789-92.

7. Hirshberg A, Thomson SR, Bade PG, Huizinga WK. Pitfalls in the management of penetrating chest trauma. Am J Surg. 1989;157(4):372-5; discussion 376.

8. Saad Júnior R. E o diafragma? Rev Col Bras Cir. 2012;39(5):351-2.

9. Perlingeiro JAG. História natural do ferimento diafragmático produzido por agente pérfuro-cortante: estudo experimental em ratos [tese]. São Paulo: Santa Casa de São Paulo, Faculdade de Ciências Médicas; 2001

10. Meyers BF, McCabe CJ. Traumatic diaphragmatic hernia. Occult marker of serious injury. Ann Surg. 1993;218(6):783-90,

11. Feliciano DV, Cruse PA, Mattox KL, Bitondo CG, Burch JM, Noon $G P$, et al. Delayed diagnosis of injuries to the diaphragm after penetrating wounds. J Trauma. 1988;28(8):1135-44.
12. Shanmuganathan K, Killeen K, Mirvis SE, White CS. Imaging of diaphragmatic injuries. J Thorac Imaging. 2000;15(2):104-11.

13. Reber PU, Schmied B, Seiler CA, Baer HU, Patel AG, Büchler MW Missed diaphragmatic injuries and their long-term sequelae. J Trauma. 1998;44(1):183-8.

14. Israel RS, Mayberry JC, Primack SL. Diaphragmatic rupture: use of helical CT scanning with multiplanar reformations. AJR Am J Roentgenol. 1996;167(5):1201-3.

15. Chiu WC, Shanmuganathan K, Mirvis SE, Scalea TM. Determining the need for laparotomy in penetrating torso trauma: a prospective study using triple-contrast enhanced abdominopelvic computed tomography. J Trauma. 2001;51(5):860-8; discussio 868-9.

16. Boulanger BR, Mirvis SE, Rodriguez A. Magnetic resonance imaging in traumatic diaphragmatic rupture: case reports. J Trauma. 1992;32(1):89-93.

17. Giannini JA, Rasslan S, Silva LE, Coimbra R, Saad Júnior R Ferimentos penetrantes tóraco-abdominais e de tórax e abdome: análise comparativa da morbidade e da mortalidade pós-operatórias. Rev Col Bras Cir. 1998;25(5):297-304.

18. Mariadason JG, Parsa MH, Ayuyao A, Freeman HP. Management of stab wounds to the thoracoabdominal region. A clinical approach. Ann Surg. 1988;207(3):335-40.

19. Saad Júnior R, Gonçalves R. Toda lesão do diafragma por ferimento penetrante deve ser suturada? Rev Col Bras Cir. 2012;39(3):2225 .

20. Perlingeiro JA, Saad R Jr, Lancelotti CL, Rasslam S, Candelária PC, Soldá SC. Natural course of penetrating diaphragmatic injury: an experimental study in rats. Int Surg. 2007;92(1):1-9.

21. Shatney $\mathrm{CH}$, Sensaki $\mathrm{K}$, Morgan $\mathrm{L}$. The natural history of stab wounds of the diaphragm: implications for a new management scheme for patients with penetrating thoracoabdominal trauma. Am Surg. 2003;69(6):508-13. 
22. Ivatury RR, Simon RJ, Weksler B, Bayard V, Stahl WM. Laparoscopy in the evaluation of the intrathoracic abdomen after penetrating injury. J Trauma. 1992;33(1):101-8; discussion 109.

23. Dureuil B, Cantineau J, Desmonts JM. Effects of upper or lower abdominal surgery on diaphragmatic function. $\mathrm{Br} J$ Anaesth. 1987;59(10):1230-5.

24. Gonçalves R. Análise da evolução natural das feridas pérfurocortantes equivalentes a $30 \%$ do diafragma esquerdo. Estudo experimental em ratos [dissertação]. São Paulo: Santa Casa de São Paulo, Faculdade de Ciências Médicas; 2008.

25. Rivaben JH, Saad Júnior R, Dorgan Neto V, Botter M, Gonçalves R. História natural do ferimento diafragmático extenso à direita: estudo experimental em ratos. Rev Col Bras Cir. 2014;41(4):26771.
26. Cameron EW, Mirvis SE. Ruptured hemidiaphragm: unusual late presentation. J Emerg Med. 1996;14(1):53-8.

27. Crandall M, Popowich D, Shapiro M, West M. Posttraumatic hernias: historical overview and review of the literature. Am Surg. 2007;73(9):845-50.

Received at: 16/02/2015

Accepted for publication: 15/05/2015

Conflict of interest: none.

Source of funding: none.

\section{Mailing address:}

Benedito Aparecido Caiel

E-mail: benedito.caiel@terra.com.br 